\title{
Comparative Study of Digital literacy in Language Learning among Indonesian Language Education and English Language Education Students in the New Normal Era
}

\author{
Arono $^{1}$, Syahriman $^{2}$, Nadrah $^{3}$, Ade Sissca Villia ${ }^{4}$, Elvi Susanti ${ }^{5}$ \\ \{arono@unib.ac.id ${ }^{1}$, syahriman@unib.ac.id ${ }^{2}$, nadrahada@gmail.com ${ }^{3}$ \} \\ University of Bengkulu, Indonesia ${ }^{1 \& 2}$, IAIN Bengkulu, Indonesia ${ }^{3}$
}

\begin{abstract}
The impact of the pandemic of Covid 19 forces students to stay on top of online learning. Technology with reasonable sophistication can be used better by English education students than Indonesian Language Education students because, in addition to language acquisition, information and applications in digital are generally Englishspeaking and are more numerous and easily obtained. This study aims to describe digital literacy in language learning among Indonesian Language Education students and English Language Education students in the new normal era. This research is a quantitative descriptive study with qualitative data verified in the form of a percentage. The data was obtained using Google forms for each of 100 students (200 samples) in Java and Sumatra randomly and by purposive sampling. The instrument uses closed questions with a Likert scale (five options) and open questions. Research results show that digital literacy in language learning among Indonesian Language Education students and English Language students in the new normal era is not significantly different, at the same level. Digital literacy in language learning is at level 4 , that is, students have been able to improve significantly (quantitatively stated) the performance of daily life activities through the use of information and technology with an average bind of $3.59(71.8 \%)$ and bind 3.46 $(69.2 \%)$. It shows that learning in networks has increased students' mastery and digital literacy abilities.
\end{abstract}

Keywords: comparative study, digital literacy skills, language learning

\section{Introduction}

Learn from each student's household to be more skilled and able to carry out effective and efficient learning. It has been done by students during the covid 19 pandemic from March 2020 to the present. Various problems arise in learning online, such as poor network conditions, inadequate facilities, inadequate internet quota, and many given tasks, until starting to feel bored with learning online. Several students utilizing the mobile learning faced some difficulty, such as the limitations of internet networks both on campus and at home, limited language learning software, ignorance of learning application examples in mobile learning, and the intensity of lecturers and students synergizing in learning a language online. less [1]. On the other hand, there are many positive things found in this bold learning, such as increasing students' skills in using technology, varied learning styles, increasing student insights and knowledge, and reducing the spread of covid 19 to be reduced. 
Several studies on digital literacy, including research conducted a web-oriented digital literacy survey as a proxy to observe skill size with a large sample. The results suggest that multiple combined variables of the survey knowledge items are better predictors of a person's actual digital literacy based on a performance test than a measure of users' self-perceived ability, a proxy traditionally used in the literature on the topic [2]. [3] There is a mismatch between institutional goals and teacher and student beliefs and practices regarding the role of technology in the curriculum. Teachers are more familiar with the software, while students are more comfortable with websites. Teacher-centered learning and paper-based learning practices. [4] That students had a statistically significant growth in information literacy competencies and critical thinking skills in learning in the digital space. [5] That there is a strong and significant relationship between digital literacy and lecturer research productivity. [6] His research offers an in-depth study of the concept by analyzing the main models of digital literacy in an international context to offer a holistic model that combines the contributions of all initiatives. His research that students' understanding of digital literacy was good and there was a perfect positive relationship between understanding digital literacy and the originality of student writing [7]. Some of these studies reveal that normal conditions in the use of technology in learning and research can improve digital literacy skills. It is different when the use of technology in conditions that do not usually require students to use technology in learning during the Covid 19 period. That is what researchers want to express in this survey research, especially for language education students, both English and Indonesian.

Mastery of technology, in this case, digital literacy for students is not new but has become a need and habit of students with its era. Sophisticated technology and facilities make students pampered in accessing and using digital in their learning. Various applications are provided, including social media, e-learning, science pages, online libraries, and various national and international research articles. [8] Information technology, especially those that prioritize visual aspects, can improve language skills more effectively. Language facilities are an entry point for digital access and use, but this is not an obstacle or difficulty for students since they can be used in various languages, both English and Indonesian. However, applications contained in digital literacy are still dominated by using English. For this reason, in this paper, the author wants to reveal the digital literacy skills of English and Indonesian students in seeing the comparison during the COVID-19 pandemic.

Digital literacy is a complex and integrated framework between sub-disciplines, namely, skills, knowledge, ethics, and creative output in a digital network environment [9]. These subdisciplines include information literacy, computer literacy, media literacy, communication literacy, and visual literacy. Digital literacy is the instrument in technology, while normative media education literacy is more in accordance with the field and needs, such as teaching digital language literacy related to language, information, connections, and redesign. Language is related to print literacy, text literacy, hypertext literacy, visual media and multimedia literacy, game literacy, cellular literacy, code, and technology literacy. Information related to search literacy, information literacy, tagging literacy. Connections relate to personal literacy, network literacy, participatory literacy, cultural and intercultural literacy. The redesign is related to remix literacy. Digital literacy is divided into two, namely "instrumental-technology" and "normative media education," each related to usage/function, and pedagogical goals [10]. It is divided into three competencies: (a) Interpreting messages; (B) Selecting messages; (c) Articulate the message. These competencies inform the goals and measures of functional, cognitive and ethical skills.

Digital literacy as a combined force and a non-quantifiable, but more flexible, skill for analyzing, selecting, and critically evaluating data and information, to exploit potential 
technology to represent and solve problems and build shared and collaborative knowledge, while cultivating awareness of one's responsibilities personal responsibility and mutual respect for rights/obligations [11]. It shows that digital literacy does not have to be a linear process, nor does it root only in specific tasks. [12] Digital literacy as the integration of five separate but interrelated literacy skills: (a) photo-visual literacy; (b) reproductive literacy; (c) information literacy; (d) branching literacy; and (e) socio-emotional literacy.These skills are presented as expressions of a culturally distinct epistemology, with a set of skills that shape different learning styles and personality types. It can be formulated that digital literacy skills are based on an understanding of digital practice; searching for information; using information; making information; endogenous motivation; exogenous motivation; operating digital devices; searching, selecting, and evaluating information, using computers and the internet; using computers and the internet to achieve goals; digital engagement; supports learning practices ([13]; [5]). Based on this, the author wants to compare the students' digital literacy skills in both English and Indonesian education.

\section{Methodology}

This research is a quantitative descriptive. Quantitative descriptive explains the existing phenomena by using numbers in quantity and quality by describing the characteristics of individuals or groups of students [14]. Quantitatively, the research data were obtained through instruments developed from students' digital literacy skills. Digital literacy competence to identify digital literacy skills and digital abilities of students consists of 11 indicators: understanding digital practice; searching for information; use information; making information; endogenous motivation; exogenous motivation; operating digital devices; searching, selecting, and evaluating information using computers, and the Internet; using computers and the Internet to achieve goals; digital engagement; supporting learning practices. These eleven indicators were developed into an instrument in research data collection, consisting of 75 questions.Each statement in this instrument has five options to choose, on a Likert scale, namely 1 ( TP = never), $2(\mathrm{P}=$ never $), 3(\mathrm{~J}=$ rarely $), 4(\mathrm{KK}=$ sometimes $)$, and $5(\mathrm{~S}=$ often $)$. The data results are interpreted based on the ability criteria of each dimension and level in the following table.

Table 1. Capability Criteria for each Dimension

\begin{tabular}{cl}
\hline Interval & \multicolumn{1}{c}{ Criteria } \\
\hline $1,00-1,80$ & Very Low, Very Less \\
$1,81-2,60$ & Low, Less \\
$2,61-3,40$ & Moderate, Enough \\
$3,41-4,20$ & High, fine \\
$4,21-5,00$ & Very High, Very Good \\
\hline
\end{tabular}

The determination of digital literacy abilities relies on the Personal-Capability Maturity Model Theory [15]. It means that if an individual does not know or care about the importance of the information and technology for everyday life (level 0); If an individual has had one or two experiences, in which the information is an important component for achieving desires and problem solving, and has involved information technology to search for it (Level 1); If an individual has repeatedly used technology to assist daily activities and already has a repetitive 
pattern in its use Level 2. If an individual already had a standard of mastery and understanding of information and technology needed, and consistently uses these standards as a reference for implementation daily activities (Level 3); If an individual has been able to significantly increase (can be stated quantitatively) the performance of his daily life activities through the use of information and technology (Level 4); If an individual has considered information and technology as an inseparable part of his daily activities, and directly or indirectly has colored his behavior and culture (part of information society or information cultured human beings) (Level 5).

\section{Results and Discussion}

The instruments used in collecting this data are obtained from 200 research samples with 100 samples from English education students and 100 students from Indonesian language education. The students come from two state universities in Java and two public universities in Sumatra. The data source's determination is based on the location that is considered representative of each area in urban and regional areas. It is because Indonesia is an archipelago, and not all of them come from regions with the same conditions. This research data was taken for about a month during July 2020 via Google Form, which was sent through groups of Indonesian and English lecturers. Then the lecturer passed on the data to students through the class leader. The questionnaire distributed around July is considered a student learning activity while studying from home because the covid 19 pandemic was carried out for approximately 3 or 4 months in even semester 2020. The results of the research and discussion can be seen in the description below.

Table 2. Comparison of Digital Literacy Abilities

\begin{tabular}{|c|c|c|c|c|c|}
\hline \multirow{2}{*}{ No } & \multicolumn{3}{|c|}{ English Education Students } & \multicolumn{2}{|c|}{$\begin{array}{c}\text { Indonesian Education } \\
\text { Students }\end{array}$} \\
\hline & Dimensi & Average & Information & Average & Information \\
\hline 1 & Understanding of digital practice & 3,11 & moderate & 2,93 & moderate \\
\hline 2 & Searching for information & 3,49 & High & 3,29 & moderate \\
\hline 3 & Using information & 3,42 & High & 3,18 & moderate \\
\hline 4 & Create information & 2,99 & moderate & 3,10 & moderate \\
\hline 5 & Endogenous motivation & 3,65 & High & 3,53 & High \\
\hline 6 & Exogenous motivation & 3,67 & High & 3,57 & High \\
\hline 7 & Operate digital devices & 3,57 & High & 3,46 & High \\
\hline 8 & Search, select, and evaluate information & 3,79 & High & 3,60 & High \\
\hline 9 & Using computers and the Internet & 3,92 & High & 3,76 & High \\
\hline 10 & Engagement using digital & 3,89 & High & 3,79 & High \\
\hline 11 & Support learning practice & 4,24 & Very High & 4,02 & High \\
\hline & Average & $\mathbf{3 , 5 9}$ & High & 3,46 & High \\
\hline
\end{tabular}

Table 2 shows that English students' digital literacy skills are high, with an average of 3.59. The indicators of English students' digital literacy skills are stated to be high, seen based on the following 11 indicators, from high to medium. Indicators of high digital literacy skills, namely supporting learning practices (4.24), using computers and the internet (3.92), engaging using digital (3.89), searching, selecting, and evaluating information $(3,79)$, motivation exogenous (3.67), endogenous motivation (3.65), operating digital devices (3.57), and looking for information (3.49), and using information (3.42), while digital literacy skills are moderate, 
namely understanding digital practice (3.11) and making information (2.99). They indicate that digital competence among students is very important in supporting the effectiveness and quality of learning from home. That means a lecturer is also very important to maintain the effectiveness of learning so that the students can be more effective in utilizing technology [16].

The indicator of digital literacy skills of Indonesian students is high with an average of 3.46, which is also seen based on the following 11 indicators, from high to moderate. High indicators of digital literacy skills, namely, supporting learning practices (4.02), engaging using digital (3.79), using computers and the internet (3.76), searching, selecting, and evaluating information (3.60), exogenous motivation (3.57), endogenous motivation (3.53), operating digital devices (3.46), and looking for information (3.29), while digital literacy skills are currently seeking information (3.29), using information (3.18), making information (3.10), and understanding digital practices (2.93). It shows that high literacy requires positive synergy from institutions or universities so that students' digital literacy skills remain high or survive and even increase in digital literacy skills in the future. [17] The concept of higher education digital literacy consists of many levels ranging from knowledge to use, and critical, creative, and collaborative use. Second, the university plays an important role in developing the digital literacy level of its students and lecturers. Third, social media platforms play a large role in various learning objectives but must identify their professional development needs.

Based on table 1 above, it shows that there is no significant difference between students' digital literacy skills in English and Indonesian. English and Indonesian students' digital literacy skills are in the same category, namely the high category or level 4 in their digital literacy skills. It means that students have improved significantly (it can be stated quantitatively) regarding the performance of their daily life activities through the use of information and technology. However, among 11 aspects of the students' digital literacy skills need to be improved, especially in understanding digital practices and making information for English Language Education students. In comparison, Indonesian Language Education students still need to improve their digital literacy skills in terms of these two aspects: added aspects of seeking information and using information. In general, students' digital literacy skills with working from home during COVID 19 have provided positive digital literacy skills for students. It can be seen in the following graph that there is no significant difference between the two.

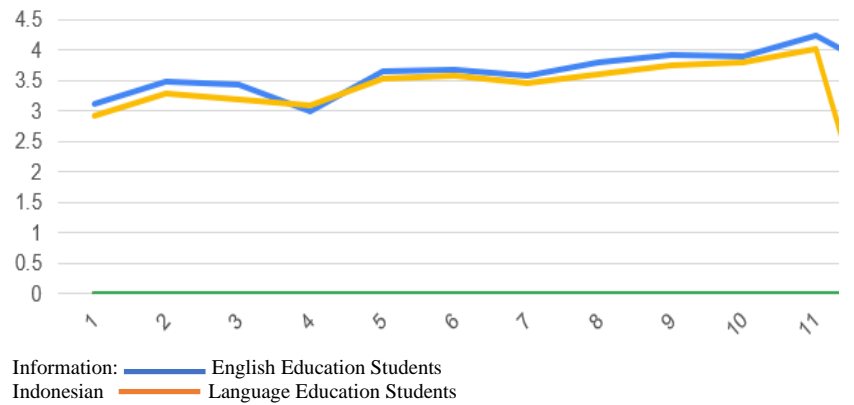

Fig 1. Student Digital Literacy Ability

Different environments do not make different literacy skills, but conditions supporting digital literacy make students better. It is the impact of the covid 19 pandemic in which the students learn from home. This condition did not immediately leave them to take advantage of technology and maximize learning through the network. The influence of the city and the region does not significantly affect students' digital literacy skills. It shows that digital literacy skills 
are not only seeing how using technology can benefit all education levels. In addition, there must be sufficient funds for digital literacy programs, in this case, universities or the government in maximizing student digital literacy [18].

Based on the results and discussion, it shows that evidence of language acquisition does not really affect a person's digital literacy. This can be seen from the level of mastery of digital literacy, both English and Indonesian students are at the same level, which is good. This is also in accordance with the results of research conducted the English students he studied regarding mastery of digital literacy were in good control. The level of understanding that students have is very normal because almost all students were born in 2000, which means they are the netizen or digital native generation [13]. This generation has worked and used digital tools for their lives since childhood. Digital native can be interpreted as a generation that develops in the digital era. They can think, and find information that is bigger, different, and in people who are older than them, it is the effect of a higher digital environment and interactions [19). According to research conducted also shows that adult students have a higher understanding of digital literacy which varies in skills according to their interests and learning styles [20].

\section{Conclusion}

Good environmental conditions will support and enhance good learning too. Students experience this both in English and Indonesian language education because the covid 19 pandemic forces them to study from home and has been able to improve students' digital literacy skills with good results or high categories. The results of this research show that there is no significant difference in digital literacy in language learning in Indonesian Language Education students and English Language Education students in the new normal era, being at the same level. Digital literacy in language learning is at the level (3.41-4.20), that is, students have been able to improve significantly (can be expressed quantitatively) the performance of their daily life activities through the use of information and technology with an average bing of 3.59 $(71.8 \%)$ ) and bind $3.46(69.2 \%)$. It indicates that online learning has improved students' mastery and digital literacy skills. However, the aspects of English education students' digital literacy skills still need to be improved, especially the aspects of understanding digital practices and making information. Indonesian Language Education students in these two aspects still need to improve their digital literacy skills, which is added to finding information and using information. It means that English Education students have a 2.6\% higher digital literacy ability than Indonesian Language Education students. In the future, students must be more creative and innovative in implementing digital literacy in language learning. It requires wider access to emphasize more specific aspects of the model, such as cross-cultural, interactional, critical listening, and the contextual dimensions of its development [21].

Acknowledgments. This research really inspires the author in addressing global problems in the field of education with the covid 19 pandemic so that it affects the mastery of digital literacy among Indonesian students. For that, it is appropriate for researchers to thank Prof. Safnil, M.A., Ph.D. who has guided the author in various research and academic fields. Prof. Wayan Arka, Ph.D. who has motivated and guided the author in research activities and visiting scholarship at the Australian National University, Canberra, Australia. 


\section{References}

[1] Arono, A. (2017). "Mobile Learning dalam Meningkatkan Pembelajaran Bahasa Mahasiswa", Seminar Internasional Riksa Bahasa XI Universitas Pendidikan Indonesia, Bandung, 16 Desember 2017.

[2] Harigittai, Eszter. (2005). Survey Measures of Web-Oriented Digital Literacy, Social Science $\begin{array}{lllllll}\text { Computer Review, } & \text { Vol. } 23 & \text { No. } & 3 & \text { Fall } & 2005 & \text { 371-379. }\end{array}$ https://dx.doi.org/10.1177/0894439305275911.

[3] Gobel, Peter and Makimi Kano. (2013). Student and Teacher use of Technology at The University Level. IADIS International Conference on Cognition and Exploratory Learning in Digital Age (CELDA 2013), https://www.researchgate.net/publication/287693725

[4] Kong, S.C. (2019). Developing Information Literacy and Critical Thinking Skills through. Domain Knowledge Learning in Digital Classrooms: An Experience of Practicing Flipped Classroom Strategy, Computers \& Education. https://dx.doi.org/10.1016/j.compedu.2014.05.009.

[5] Yazon, A. D., Ang-Manaig, K., Buama, C. A., \& Tesoro, J. F. (2019). Digital Literacy, Digital Competence and Research Productivity of Educators, Self-Assessment Tool of the European Digital Competence Framework for Educators (DigComEdu) Universal Journal of Educational Research 7(8): 1734-1743, 2019 http://www.hrpub.org. https://dx.doi.org/10.13189/ujer.2019.070812.

[6] Escoda, Ana Perez, Rosa García-Ruizb, and Ignacio Aguaded. (2919). Dimensions of digital literacy based on five models of development / Dimensiones de la alfabetización digital a partir de cinco modelos de desarrollo. Cultura y Educación / Culture and Education, 2019 Vol. 31, No. 2, 232-266, https://doi.org/10.1080/11356405.2019.1603274

[7] Muthmainnah, N. (2019). A Correlational Study of Digital Literacy Comprehension Toward Students' Writing Originality. Langkawi: Journal of The Association for Arabic and English, 5 (1), 45-54. http://dx.doi.org/10.31332/lkw.v5i1.1151

[8] Meskill, C.(1996). "Listening Skills Development Through Multimedia". Journal of Educational Multimedia and Hypermedia. (1996) 5 (2), 179-201. Department of Educational Theory and Practice, University at Albany, State University of New York, Albany, USA.

[9] Calvani, A., Cartelli, A., Fini, A., and Ranieri, M. (2008). Models and Instruments for Assessing Digital Competence at School. Journal of e-Learning and Knowledge Society, Vol. 4, n. 3, September 2008 (pp. 183 - 193).

[10] Gapski, H. (2007). Some Reflections on Digital Literacy. Proceedings of the 3rd International Workshop on Digital Literacy (pp. 49-55). Crete, Greece: CEUR-WS.org. Retrievedonline February 22, 2010 from: http://ceur-ws.org/Vol-310/paper05.pdf

[11] Calvani, A., Fini, A., and Ranieri, M. (2009). Assessing Digital Competence in Secondary Education - Issues, Models and Instruments. (M. Leaning, Ed.) Issues in Information and Media Literacy: Education, Practice and Pedagogy, 153-172.

[12] Aviram, A., and Eshet-Alkalai, Y. (2006). Towards a Theory of Digital Literacy: Three Scenarios for the Next Steps. European Journal of Open, Distance and E-Learning. Retrieved online February 23, 2010 from: http://www.eurodl.org/index.php?p=archives\&year=2006\&halfyear=1\&article=223

[13] Soomro, Kamal Ahmed, Kale, Ugur, Curtis, Reagan, Akcaoglu, Mete, \& Bernstein, Malayna. (2018). Development of an instrument to measure faculty's information and communication technology access (FICTA). Education and Information Technologies, Vol 23(1), 253-269. https://dx.doi.org/10.1007/s10639-017-9599-9

[14] Howell, D. C. (2011). Fundamental statistics for the behavioral sciences. California: Wadsworth Cengage Learning.

[15] Curtis, B., Hefley, B., and Miller, S. (2009). People capability maturity model (P-CMM) version 2.0 (No. CMU/SEI-2009-TR-003). Carnegie-Mellon Univ Pittsburgh Pa Software Engineering. Inst.

[16] Elstad, Eyvind and Knut-Andreas Christophersen. (2017). Perceptions of Digital Competency among Student Teachers: Contributing to the Development of Student Teachers' Instructional SelfEfficacy in Technology-Rich Classrooms. https://dx.doi.org/10.3390/educsci7010027 www.mdpi.com/journal/education. 
[17] Akayoğlu, S., Satar, M., Dikilitas, K., Cirit, N. C., \& Korkmazgil, S. (2020). Digital literacy practices of Turkish pre-service EFL teachers. Australasian Journal of Educational Technology, 2020, 36(1).

[18] Ukwoma, S. C., Iwundu, N. E., \& Iwundu, I. E. (2016). Digital literacy skills possessed by students of UNN, implications for effective learning and performance. New Library World.

[19] Prensky, M. (2001). Digital Natives, Digital Immigrant. On the Horizon, 1.

[20] Noh, Y. (2017). A Study on the Effect of Digital Literacy on Information Use Behavior. JoLis (Journal of Librarianship and Information Science, 26-56.

[21] Arono, A. (2013). Pembelajaran Keterampilan Menyimak melalui Teknologi Informasi, Jurnal Kajian Bahasa, Sastra, dan Pembelajarannya, ISSN 1412-0712 Volume 13 Nomor 2, UPI Okteober 2013. https://doi.org/10.17509/bs_jpbsp.v13i2.286 